\title{
Paracoccidioidomycosis: an unusual presentation with a rapid progression
}

Paracoccidioidomicose: uma forma incomum com progressão muito rápida

Patrícia Duarte Deps ${ }^{1}$, Marisa Barros das Neves ${ }^{2}$ and Lauro F.S. Pinto Neto ${ }^{2}$

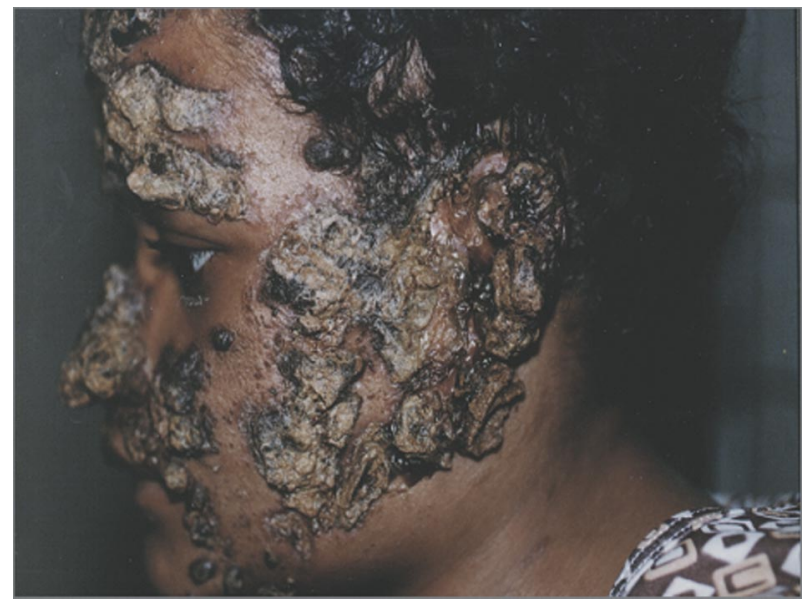

A

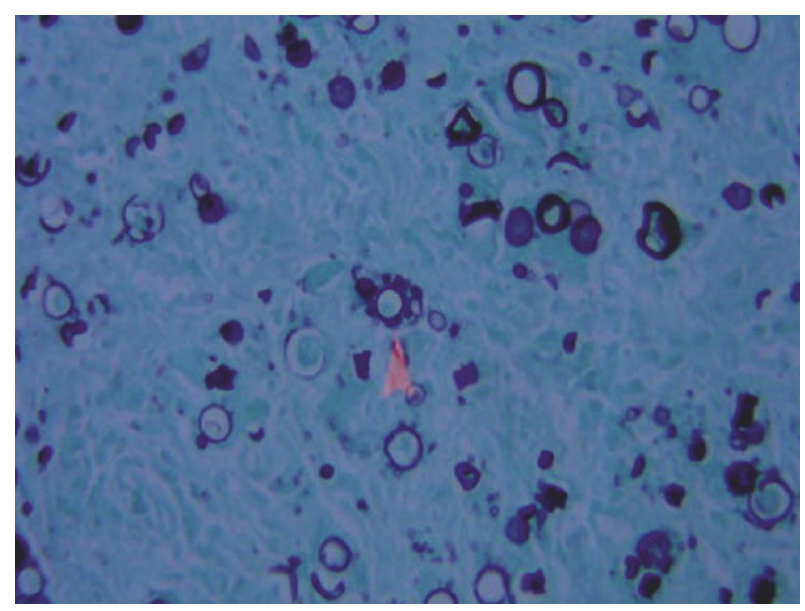

B

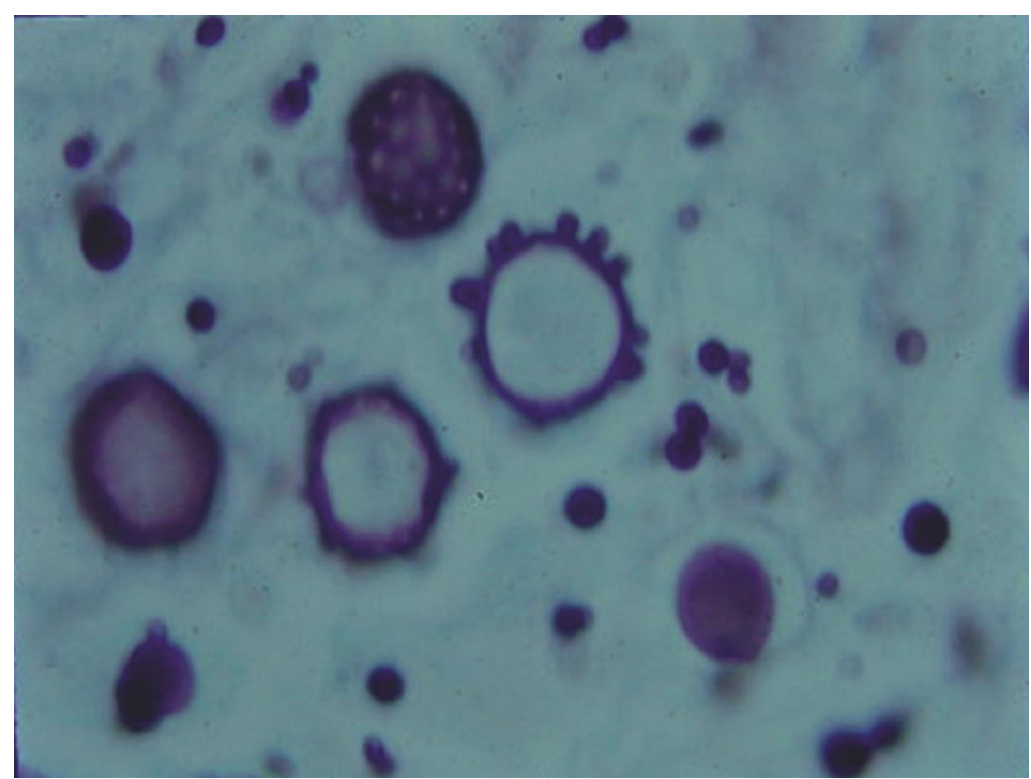

C

1. Departamento de Medicina Social do Núcleo de Doenças Infecciosas da Universidade Federal do Espírito Santo, Vitória, ES. 2. Departamento de Clínica Médica da Faculdade de Medicina da Santa Casa de Misericórdia de Vitória (EMESCAM), Vitória, ES.

Address to: Prof. Lauro F.S. Pinto Neto. Av. Nossa Senhora da Penha 2190, Bairro Santa Luiza, Caixa Postal 5135, 29045-402 Vitória, ES. Tel: 27 3323-1091

e-mail: climedica@ emescam.br; laurofp@ zaz.com.br.

Recebido em 30/6/2003

Aceito em 18/6/2004 
A 18-year-old woman, from Guaçuí, State of Espírito Santo, was admitted to the Internal Medicine ward of the Santa Casa of Vitoria Hospital, in Vitoria, ES, due to extensive cutaneous lesions on her face and scalp. Five months before admission, there were lesions only on her forehead. The patient was treated with trimethoprim-sulfamethoxazole for 4 weeks with partial improvement. She correlated the rapid progression of the lesions on her face, four weeks before admission, to emotional depression which started after her brother's death. There were no systemic complaints. Physical examination revealed skin lesions, hard papules and nodules, single formations of chestnut-brown plaques of verrucous shape spreading over the face, ear and scalp; some lesions revealed purulent secretion (Figure A) and cutaneous myiasis. A typical moriform lesion at the hard palate, on her oral mucosa was observed. There were cervical lymph nodes varying from 1 to 2 centimeters in diameter. Lungs and heart auscultation were normal. The abdomen was normal, with no evidence of mass or tenderness. Chest x-rays did not show alterations. HIV-1 and HIV-2 serologies resulted negative. Histologic examination of the skin lesion disclosed pseudoepitheliomatous hyperplasia with severe granulomatous inflammation and many typical rounded refractile cells of Paracoccidioides brasiliensis (Figures B and $C$ ). The patient was treated with intravenous amphotericin $B$ (total dosage of 2,075mg) for 63 days. Her condition improved with complete resolution of the mucocutaneous lesions. She was discharged from Hospital and maintained on oral trimethoprimsulfamethoxazole.

Paciente de 18 anos, do sexo feminino, procedente de Guaçuí, Espírito Santo e foi admitida na enfermaria de Clínica Médica da Santa Casa de Misericórdia de Vitória, ES, com lesões cutâneas extensas em face e couro cabeludo, de 5 meses de evolução. Inicialmente, as lesões eram localizadas apenas na fronte, sendo tratadas com antibióticos sulfamídicos por 4 semanas com melhora inicial do quadro. A paciente atribui a rápida piora das lesões à depressão após a morte do irmão. Não havia queixas sistêmicas. Ao exame clínico evidenciaram-se lesões do tipo pápulas e nódulos de consistência dura, isolados ou formando placas acastanhadas, com aspecto verrucoso, abrangendo face, pavilhões auriculares e couro cabeludo, algumas lesões apresentavam secreção purulenta ( Figura A) , com presença de miĺase cutânea. 0 exame da mucosa oral mostrou lesão típica de estomatite moriforme no palato duro. Apresentava ainda vários linfonodos cervicais palpáveis variando de um a dois centímetros de diâmetro. A asculta pulmonar e cardíaca eram normais. Não foram evidenciadas massas palpáveis ao exame do abdome. A radiografia de tórax era normal. As sorologias para o HIV-1 e 2 revelaram-se negativas. 0 estudo histológico de fragmento retirado de lesão da face mostrou hiperplasia pseudoepiteliomatosa com processo inflamatório granulomatoso e muitas células bi-refringentes arredondadas típicas do Paracoccidioides brasiliensis ( Figuras $\mathrm{B} \mathrm{eC}$ ) 0 tratamento foi realizado com anfotericina B intravenosa (dose total de 2,75mg) durante 63 dias. Houve melhora completa das lesões cutâneas e da mucosa oral. A paciente foi referenciada para tratamento ambulatorial com sulfametoxazol-trimetoprim.

\section{REFERENCES}

1. Blotta MH, Mamoni RL, Oliveira SJ, Nouér AS, Papaiordanou PM, Gouveia A, Camargo ZP. Endemic regions of paracoccidioidomycosis in Brazil: a clinical and epidemiologic study of 584 cases in the Southeast region. American Journal of Tropical Medicine and Hygiene 61:390-394, 1999.

2. Paniago AM, Aguiar JI, Aguiar ES, da Cunha RV, Pereira GR, Londero AT, Wanke B. Paracoccidioidomicoses: estudo clínico e epidemiológico de 422 casos observados no Estado do Mato Grosso do Sul. Revista da Sociedade Brasileira de Medicina Tropical 36:455-459, 2003.

3. Sampaio APS. Paracoccidioidomicose. In: Talhari S, Neves RG (eds) Dermatologia Tropical, 1ำ edição, Editora Médica e Científica Ltda ( MEDSI), São Paulo p.147-165, 1997. 